Петро Макушев,

докт. юрид. наук, професор,

декан юридичного факультету

Дніпровського гуманітарного університету

\title{
РЕЦЕНЗІЯ НА МОНОГРАФІЮ ШАРОЇ АННИ АНАТОЛІЇВНИ «ТЕОРІЯ ПРИНЦИПІВ АДМІНІСТРАТИВНО-ПРОЦЕДУРНОГО ПРАВА»
}

У сучасних умовах реформування й постійної модифікації відносин, які складаються між приватними та публічними особами (зокрема, щодо вирішення індивідуальних адміністративних справ), особливої наукової ваги набирають дослідження, спрямовані на розв'язання теоретичних і правозастосовних проблем адміністративного права. Одним із таких досліджень стала монографія А. А. Шарої «Теорія принципів адміністративно-процедурного права», у якій автор намагається комплексно дослідити складну юридичну природу принципів адміністративно-процедурного права 3 огляду на їх багатосторонній зміст.

Рецензована монографія належить до числа тих, які на сучасному етапі розвитку адміністративно-правової науки, реалізації чинного законодавства та підготовки проєктного є актуальною як у теоретичному, так і в прикладному плані, адже сучасний період розвитку української держави характеризується кардинальними змінами в різних сфеpax, у тому числі у відносинах між державою та приватними особами. Набирає обертів переорієнтація таких відносин на «сервісний», «обслуговуючий» характер. 3 огляду на те, що саме взаємодія держави і приватних осіб становить центральну ідею адміністративно-процедурного права, набуває нагальності дослідження «фундаменту», «підгрунтя», «основи» таких відносин. Таким базисом є саме принципи адміністративнопроцедурного права, розгляду специфіки яких присвячена робота.

У своїй структурі монографія передбачає наявність передмови, чотирьох розділів, висновків і списку використаних джерел, що зумовлює поступове й логічно організоване з'ясування, характеристику, аналіз та вирішення конкретної проблеми. Монографія
$€$ наочним виданням, яке значно полегшуе сприйняття змісту, сутності й ролі адміністративно-процедурного права для регулювання окремої групи суспільних відносин, а також його місця в системі адміністративного права. Водночас у ній розкрито категорію принципів адміністративно-процедурного права змістовно та сутнісно. Зазначене пояснює необхідність і своєчасність появи результату наукової роботи.

Перший розділ монографії присвячено генезі системи уявлень про принципи права як основи сучасного розуміння принципів адміністративно-процедурного права як інтегративної правової категоpiї, де автором проаналізовано принципи права як первісну категорію, від якої походить досліджуване поняття, і доведено, що вони $є$ комплексною правовою інтегративною категорією. Також досліджено адміністративно-процедурне право як сферу об'єктивізації принципів, звернено увагу на наукову дискусію щодо його місця в системі адміністративного права та зроблено висновок про його статус як підгалузі адміністративного права. Окремий підрозділ присвячений визначенню поняття й характерних ознак принципів адміністративно-процедурного права, де сформульовано авторське визначення цієї категорії та запропоновано власний перелік характеристик із розкриттям їх змісту. Також увагу приділено історіографії дослідження принципів адміністративно-процедурного права у вітчизняній адміністративно-правовій науці, за результатами розгляду якої автором запропоновано власну періодизацію такого дослідження

У другому розділі монографії розкрито теоретико-методологічні основи теорії принципів адміністративно-процедурного

${ }^{1}$ Шарая А.А. Теорія принципів адміністративно-процедурного права : монографія. Запоріжжя : Видавничий дім «Гельветика», 2019. 400 с. 
права. Зокрема, присвячено увагу класифікації та видам принципів адміністративнопроцедурного права, де як авторську ідею запропоновано використання декількох критеріїв для класифікації принципів адміністративно-процедурного права, що дало змогу краще з'ясувати їх ресурс. Також у розділі проаналізовано систему принципів адміністративно-процедурного права та виокремлено притаманні їй ознаки.

Третій розділ присвячений безпосередньо характеристиці принципів адміністративнопроцедурного права. Так, автором окремо детально проаналізовано верховенство права як базовий принцип адміністративно-процедурного права, а також універсальні й інституційні принципи адміністративно-процедурного права. Зауважено, що універсальні принципи адміністративно-процедурного права є відображенням загальних положень, характерних для відносин публічної адміністрації та приватних осіб (у процедурному аспекті), відповідають взаємовизнаним і нормативно закріпленим правилам таких правовідносин, об'єктивно відтворюють сутність реалізації владних повноважень суб'єктами публічної адміністрації, $є$ фундаментальною установкою, визнаною суспільством, та закріплені нормативно. Отже, універсальні принципи адміністративно-процедурного права $€$ «каркасом» для всіх адміністративних процедур, мають загальний, всеохоплюючий, глобальний характер. Інституційними принципами адміністративно-процедурного права є правила, норми управлінської діяльності, відповідно до яких забезпечується реалізація окремих видів адміністративних процедур. 3 огляду на існування досить широкого їх спектру й переліку зазначені принципи тією чи іншою мірою відображають сутність та особливості таких адміністративних процедур. Інституційні принципи адміністративно-процедурного права $є$ узагальненням практичного позитивного управлінського досвіду та грунтуються на певних законах і закономірностях суспільного розвитку.
Четвертий розділ монографії містить узагальнення щодо концептуальних засад реалізації принципів адміністративно-процедурного права. Так, автором досліджено питання реалізації принципів адміністративно-процедурного права, ефективність такої реалізації та її проблеми. Окрему увагу присвячено формуванню концепції реалізації принципів адміністративно-процедурного права.

Розділи й підрозділи рецензованої монографії викладені в логічній послідовності 3 урахуванням теоретико-правових та адміністративно-правових наукових надбань. $\mathrm{y}$ роботі звернено увагу на європейський досвід урегулювання відповідної сфери суспільних відносин. Вдалою вважаємо структуру монографії, яка включає в себе наукові коментарі та власні пропозиції автора щодо вдосконалення системи принципів адміністративно-процедурного права й ефективності їх реалізації.

Монографія відрізняється науковою обгрунтованістю та достовірністю викладеної в ній інформації, яка подається з урахуванням останніх змін, що відбулися в чинному законодавстві України. У ній проведено науковий аналіз значної кількості наявних нормативно-правових актів, а також проєктів нормативно-правових актів.

У монографії А. А. Шарої можна знайти низку полемічних положень, які викликані новизною такої складної проблеми, як адміністративно-процедурне право та його принципи. Водночас ознайомлення із цією роботою дає змогу зробити висновок, що це одне 3 перших комплексних теоретичних досліджень юридичної природи принципів адміністративно-процедурного права. Викладені в ній положення є науково обгрунтованими й виваженими, що створює в читача цілісне уявлення про досліджувану проблему. Загалом монографію написано на високому рівні, вона вирізняється глибиною дослідження та може здійснити відповідний внесок у науку адміністративного права. 